\title{
Green Tea and Bilberry Protective Effect against Gentamicin-Induced Nephrotoxicity in Rats
}

\author{
Milica Veljković1, Dragana R. Pavlovićé, Ivan Ilić3 ${ }^{3}$ Dušan Sokolović ${ }^{4}$ \\ ${ }^{1}$ University of Niš, Faculty of Medicine, Department of Physiology, Niš, Serbia \\ ${ }^{2}$ Faculty of Medicine, University of Niš, Department of Pharmacy, Niš, Serbia \\ ${ }^{3}$ Faculty of Medicine, University of Niš, Department of Pathology, Niš, Serbia \\ ${ }^{4}$ Faculty of Medicine, University of Niš, Department of Biochemistry, Niš, Serbia
}

\section{SUMMARY}

The aim of our study was to investigate if green tea and bilberry have protective effect on gentamicin-induced kidney damage, when applied together, and to make a connection between their effects.

GM group of rats received only gentamicin, GT group received green tea only, B group received only bilberry, whereas control (C) group received saline only. GT+GM group received green tea together with gentamicin, and $B+G M$ group received bilberry together with gentamicin.

Biochemical analysis showed significantly increased urea and creatinine levels in GM group when compared to groups that also received bilberry or green tea. Histological analysis showed complete disruption of glomerular basal membrane as well as basal membranes of both proximal and distal tubules in GM group. These destructive effects were significantly milder and limited only to proximal tubules when bilberry or green tea was applied simultaneously with gentamicin.

Both green tea and bilberry protective effect on gentamicin-induced nephrotoxicity is manifested because of their strong antioxidant activity. Since they are strong antioxidants, widely distributed in nature, they can offer available and inexpensive adjuvant therapy in Gram-negative infections, which can relieve gentamicin nephrotoxicity, but will not affect its bactericidal effect.

Key words: gentamicin, nephrotoxicity, green tea, bilberry, rat

Corresponding author:

Milica Veljković

e-mail: milica.veljkovic@gmail.com 


\section{INTRODUCTION}

Gentamicin (GM) still remains an important aminoglycoside antibiotic against life-threatening bacterial infections despite nephrotoxicity being a major problem for its effective long-term clinical use (1). The main reason why kidney is so susceptible to GM-induced impairment is its high blood flow $(20 \%$ of stroke volume). Although the very mechanism by which GM causes nephrotoxicity remains unclear and is still vastly debated, it is considered that oxidative stress has a key role in it. General features of GM kidney damage include, besides increased blood urea and creatinine, necrosis of tubular cells, reduction in glomerular filtration and kidney blood flow (2).

Recently, naturally occurring dietary substances have been in the focus of research. Particularly, their role in prevention and alleviation of chronic and life-style diseases caused by oxidative stress have been investigated. In our research, for such substances, we chose green tea (GT) and bilberry (B) as powerful antioxidants and functional foods. Our previous experiments $(3,4)$ were extended to investigation of their possible protective effect on the basal membrane destruction caused by GM.

\section{MATERIALS AND METHODS}

\section{Preparation of ethanolic green tea and methanolic bilberry extracts}

Green tea and bilberry extracts were prepared in the same way as described in our previous papers $(3,4)$.

\section{Animals}

Forty-eight adult Wistar rats, both male and female (8 rats/group), weighing 200-250 g, fed with standard rat chow diet and water ad libitum, were prepared for this experiment and divided into six groups.

Control (C) group was given only saline intraperitoneally for 15 days. Green tea (GT) group was given GT extract orally ( $150 \mathrm{mg} / \mathrm{kg} /$ day) in the course of 15 days. Bilberry (B) group was orally given $B$ extract $(100 \mathrm{mg} / \mathrm{kg} /$ day $)$ during 15 days. Nephrotoxicity in GM group was induced by intraperitoneal administration of GM $(100 \mathrm{mg} / \mathrm{kg} /$ day) for the last eight days of experiment. The other two groups (GT+GM and $\mathrm{B}+\mathrm{GM})$ received orally the same dosage of GT and B extracts, respectfully, during the whole 15 days of experiment, and for the last 8 days they also received GM.

The rats were sacrificed $24 \mathrm{~h}$ after the last injection under ketamine anesthesia. Blood samples were collected from the aorta for biochemical analysis. Kidneys were removed for homogenate preparation. All experimental procedures were conducted in accordance with the principles for the care and use of laboratory animals for scientific purposes and approved by the local Ethical Committee.

\section{Biochemical analysis}

Aorta blood samples were analyzed for markers of renal failure, urea and creatinine in the laboratory of the Clinic of Nephrology, Clinical Center Niš.

\section{Histological analysis}

After kidney removal, tissues were fixed in $10 \%$ paraformaldehyde, dehydrated in ascending graded series of alcohol and embedded in paraffin. Kidney pieces were cut into $4 \mu \mathrm{m}$ sections and stained with Jones according to conventional staining protocol. After that, tissues were examined under a light microscope.

\section{Statistical analysis}

All the obtained parameters were expressed as the mean \pm SD. Statistical significance between different groups was determined by one-way analysis of variance (ANOVA) followed by Tukey post hoc test for multiple comparisons (Graphpad Prism version 5.03, San Diego, CA, USA). The value less than 0.05 was considered significant.

\section{RESULTS}

\section{Biochemical analysis}

In GM-treated group, there was significant rise in creatinine and urea levels in comparison to $C$ group $(p<0.001)$ which proves acute renal failure caused by GM. In groups where both GT and B were co-administered with GM $(\mathrm{GT}+\mathrm{GM}$ and $\mathrm{B}+\mathrm{GM}$ group), the values were significantly lower when 
compared to GM group. However, when compared to control group, these values were higher, but not significantly. There was no statistical significance between urea and creatinine levels in groups that received extracts only (GT and B group) in comparison to $\mathrm{C}$ group (Figure 1 and 2).

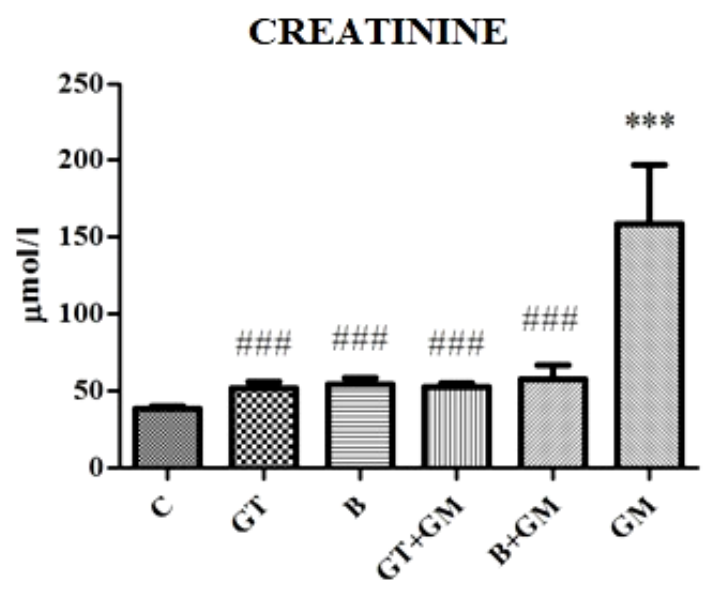

Figure 1. Rat creatinine concentrations

\#\#\# $\mathrm{p}<0.001$ vs. GM

${ }^{* * *} \mathrm{p}<0.001$ vs.C

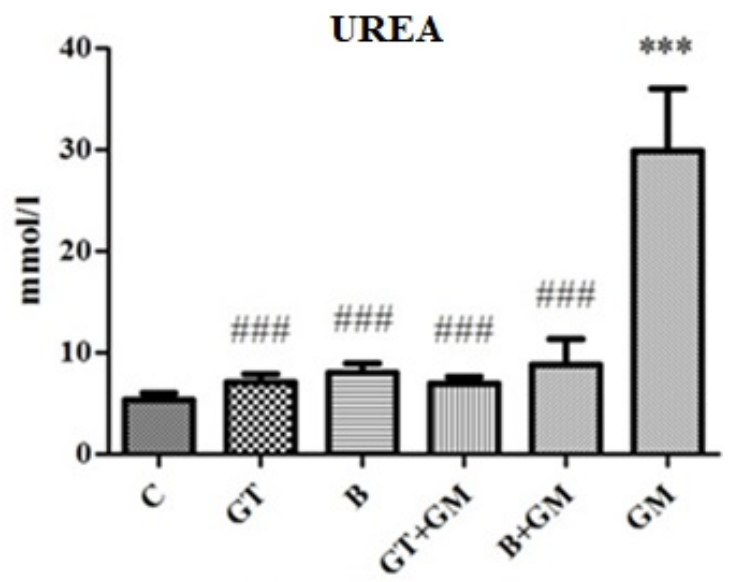

Figure 2. Rat urea concentrations

\#\#\# $\mathrm{p}<0.001$ vs. GM

*** $\mathrm{p}<0.001$ vs.C

\section{Histological analysis}

Control group, as well as groups treated with GT or B only showed normal histological tissue features. GM group showed complete disruption of glomerular basal membrane, as well as basal membranes of both proximal and distal tubules. In groups where extracts were co-administered with GM (GT+GM and B+GM group), the disruption of basal membrane was milder. Although focal membrane parts of proximal tubules were destructed, destructive effects were restricted only to those parts of nephrons. Glomeruli and distal tubule parts of basal membrane were intact in these two groups (Figure 3).

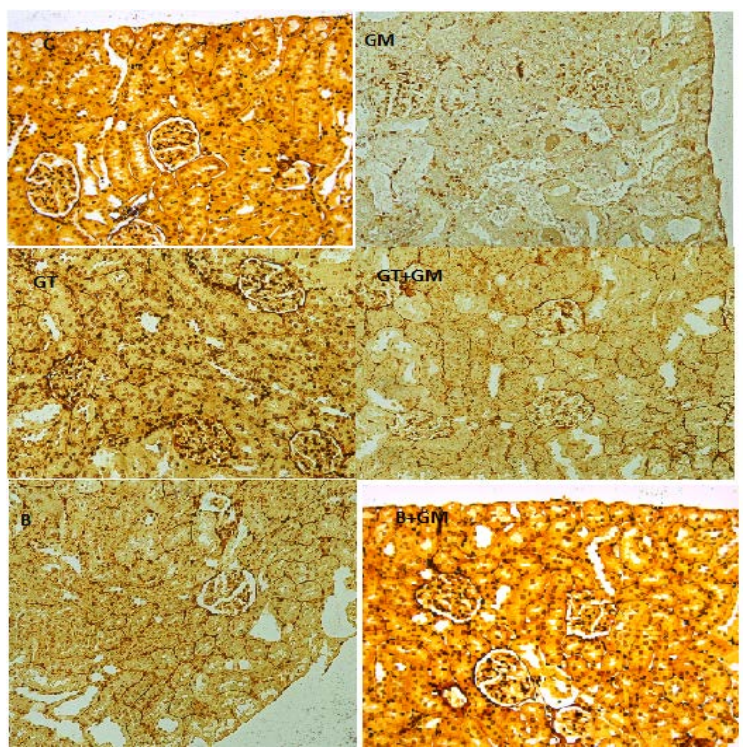

Figure 3. Histopathological view of rat kidneys from all examined groups (Jones $x$ 200)

\section{DISCUSSION}

The received doses and periods of treatment with GM, GT and B were established based on literature and our previous experience $(3,4)$.

In the management of Gram-negative infections, GM has still maintained the leading role, despite the introduction of newer less toxic antimicrobial agents. GM shows concentration-dependent bactericidal activity, but also concentrationdependent nephrotoxicity. The main reason for GM nephrotoxicity is its water solubility and thus elimination by glomerular filtration. While being eliminated, a part of GM gets reabsorbed in proximal tubules, where it achieves the highest concentration and consequently the highest nephrotoxicity (5).

The experimental data point to the fact that the main mediator of GM nephrotoxicity is oxidative stress and it manifests through tubular, glomerular and vascular damage $(5,2)$. Therefore, it might be 
useful to test the efficacy of natural antioxidants, such as GT and B against this kind of renal impairment.

In our study, GM-induced renal damage was confirmed by both biochemical analysis of urea and creatinine (Figure 1 and 2), as parameters of acute renal failure, and histopathological examination of rat kidneys (Figure 3). GM produced a significant elevation in blood urea and serum creatinine levels after 8 days of its injection when compared to untreated control rats. On the other hand, coadministration of either GT or B together with GM significantly reduced both urea and creatinine levels when comparing to the treatment of GM alone. Administration of either GT or B alone had no significant effect on urea and creatinine levels when compared to untreated control group of rats. These results point out that GM caused reduction in glomerular filtration and kidney damage which were alleviated through simultaneous administration of GT and B.

GM-induced renal damage was also confirmed by histopatological investigation (Figure 3). Rats treated with it (GM group) showed a widespread damage to the kidney structure, as in our previous experiments, where we assessed it with the help of HE and PAS tissue staining $(3,4)$. In this study, we extended our research to prove a deteriorating effect that GM exerts on basal membranes of various nephron parts. When applied alone, GM manifested complete basal membrane disruption of glomeruli, proximal and distal tubules. However, when applied together with GT or B, basal membrane disruption was milder. It was focal and limited only to proximal tubules, while glomeruli and distal tubules remained intact. These results also prove nephrotoxicity of GM, but also its alleviation through simultaneous treatment with GT or B. They also indicate that the most vulnerable part for GMinduced kidney damage are proximal tubules, since GT and B were not able to stop their damage as they successfully managed to do with the other parts of the nephron.
Our results are in accordance with the results of other investigators (5). GM causes toxicity in cells where it mostly accumulates (6). Since in kidney these are the cells of the proximal tubules, they are affected the most by its cytotoxic effects, while distal tubules and collecting duct cells are significantly less affected (7). GM enters the proximal tubule cells through the process of endocytosis. After the entrance, it is being transported to various cellular organelles, where it binds to membrane phospholipids, alter their function and lead to phospholipidosis. Phospholipidosis is both found in humans (8) and experimental animals (9) and is directly linked to GM nephrotoxicity by other authors (2).

Having established in our previous experiments that GM causes oxidative stress $(3,4)$, we tried to explore the possibility of ameliorating it by simultaneous administration of antioxidant sources. For this purposes, we chose green tea and bilberry. They are considered to be functional food, powerful antioxidants, freely available in nature and widely accepted in every day diet.

\section{CONCLUSION}

Our study shows that both green tea and bilberry ameliorate functional and structural damage caused by gentamicin. Since they are strong antioxidants, widely distributed in nature, they can offer available and inexpensive adjuvant therapy in Gram-negative infections, which can relieve GM nephrotoxicity, but will not affect its bactericidal effect.

\section{Conflict of interest}

The authors report no conflicts of interest.

\section{Acknowledgements}

This work was supported by the Ministry of Science and Technological Development, Republic of Serbia (grant 43012). 


\section{References}

1. Khan SA, Priyamvada S, Farooq N, et al. Protective effect of green tea extract on gentamicin-induced nephrotoxicity and oxidative damage in rat kidney. Pharmacol Res 2009; 59(4): 254-62. https://doi.org/10.1016/j.phrs.2008.12.009

2. Ranđelović P, Veljković S, Stojiljković N, et al. Gentamicin nephrotoxicity in animals: Current knowledge and future perspectives. EXCLI J 2017; 16: 388-99.

3. Veljković M, Pavlović DR, Stojiljković N, et al. Morphological and morphometric study of protective effect of green tea in gentamicin-induced nephrotoxicity in rats. Life Sci 2016; 147: 85-91. https://doi.org/10.1016/j.lfs.2016.01.035

4. Veljković M, Pavlović DR, Stojiljković N, et al. Bilberry: Chemical Profiling, in Vitro and in Vivo Antioxidant Activity and Nephroprotective Effect against Gentamicin Toxicity in Rats. Phytother Res 2017; 31(1): 115-23.

https://doi.org/10.1002/ptr.5738

5. Acharya CR, Thakar HN, Vajpeysee SK. A study of oxidative stress in gentamicin induced nephrotoxicity and effect of antioxidant vitamin $C$ in Wistar rats. Natl J Physiol Pharm Pharmacol 2013; 3(1): 14-20.

https://doi.org/10.5455/njppp.2013.3.14-20

6. Verpooten GA, Giuliano GA, Verbist L, et al. Once-daily dosing decreases renal accumulation of gentamicin and netilmicin. ClinPharmacolTher 1989; 45: 22-7.

https://doi.org/10.1038/clpt.1989.4

7. Fujiwara K, Shin M, Matsunaga $H$, et al. Lightmicroscopic immunocytochemistry for gentamicin and its use for studying uptake of the drug in kidney. Antimicrob Agents Chemother 2009; 53: 3302-7.

https://doi.org/10.1128/AAC.01627-08

8. De Broe ME, Paulus GJ, Verpooten RA et al. Early effects of gentamicin, tobramicin and amikacin on the human kidney. Kidney Int 1984; 25: 643-52. https://doi.org/10.1038/ki.1984.69

9. Nonclercq D, Wrona S, Toubeau G et al. Tubular injury and regeneration in the rat kidney following acute exposure to gentamicin: a time-course study. Ren Fail 1992; 14: 507-21. https://doi.org/10.3109/08860229209047660 


\title{
Zaštitni efekti zelenog čaja i borovnice na gentamicinom uzrokovanu nefrotoksičnost kod pacova
}

\author{
Milica Veljković1, Dragana R. Pavlović2 ${ }^{2}$ Ivan Ilić3, Dušan Sokolović ${ }^{4}$ \\ ${ }^{1}$ Univerzitet u Nišu, Medicinski fakultet, Institut za fiziologiju, Niš, Srbija \\ ${ }_{2}^{2}$ Univerzitet u Nišu, Medicinski fakultet, Katedra za farmaciju, Niš, Srbija \\ ${ }^{3}$ Univerzitet u Nišu, Medicinski fakultet, Institut za patologiju, Niš, Srbija \\ ${ }^{4}$ Univerzitet u Nišsu, Medicinski fakultet, Institut za biohemiju, Niš, Srbija
}

\section{S A ŽETAK}

Cilj našeg istraživanja bio je da ispitamo da li zeleni čaj i borovnica ispoljavaju zaštitni efekat na gentamicinom izazvano oštećenje bubrega, kada se primene zajedno sa gentamicinom, kao i da napravimo vezu između njihovih efekata.

GM grupa pacova tretirana je samo gentamicinom, GT grupa samo zelenim čajem, B grupa samo borovnicom, a kontrolna grupa samo fiziološkim rastvorom.

Biohemijska analiza pokazala je značajno povećane nivoe uree i kreatinina u GM grupi, u odnosu na grupe koje su istovremeno tretirane borovnicom ili zelenim čajem. Histološko ispitivanje pokazalo je potpuno uništenje glomerulske bazalne membrane, ali i bazalne membrane proksimalnih i distalnih tubula pacova u GM grupi. Ovi efekti oštećenja bili su znatno ublaženi, ali i ograničeni samo na proksimalne tubule, kada su borovnica ili zeleni čaj bili primenjeni zajedno sa gentamicinom.

Zaštitni efekti i zelenog čaja i borovnice na nefrotoksičnost bubrega izazvanu gentamicinom javljaju se zbog njihove jake antioksidativne aktivnosti. Pošto su to antioksidansi koji su široko rasprostranjeni $u$ prirodi, mogu da ponude dostupnu i povoljnu pomoćnu terapiju u lečenju Gram-negativnih infekcija, koja bi mogla da ublaži gentamicinsku nefrotoksičnost, ali ne bi uticala na baktericidni efekat gentamicina.

Ključne reči: gentamicinska nefrotoksičnost, zeleni čaj, borovnica, pacov 